\title{
Can people with a name that is part-Vietnamese and part- foreign represent Vietnamese (cultural identity)?
}

\author{
Bảo Thiên Ngô \\ Silicon Valley, California, US \\ June 25,2020 \\ https://www.quora.com/profile/Bảo-Thiên-Ngô \\ *Response to the question: https://www.quora.com/Why-do-so-many-people-with-a- \\ name-that-is-half-Vietnamese-half-foreign-answer-questions-about-Vietnam-Can-they- \\ represent-Vietnamese
}

And my first thought was: When did Vietnamese people start adopting foreign names, and why?

And we can split the answer to that question into two parts.

The first part has to consider: Are Chinese names considered foreign? When did the surname Nguyễn, Trần, Bùi, Phạm, etc. become first introduced into the Vietnamese language? Where did those people who had those surnames originally live? I can't answer these questions yet because I am still studying Vietnamese and Chinese history to see how culture migrated or originated, and we all know that Vietnamese culture was very influenced by its Chinese neighbor.

The second part puts the whole Chinese and Vietnamese cultural identity messiness aside and looks more at: When did Vietnamese people adopt Western names? And I think this is easier to answer, which is that this became more prevalent in the late 20thcentury as soon as there was a change in Vietnamese people's access to communication technology and a change in their environment. Before the 20th-century, your average Vietnamese civilian probably only knew people within a $30 \mathrm{~km}$ radius, and the Vietnamese leadership could probably communicate with civilizations within the Sinosphere and their neighbors in Southeast Asia. Then came the introduction of the modern Vietnamese writing system (chũ̃ quốc ngũ), French colonialism, radio, telephone, and the internet, combined with a mass migration of Vietnamese starting after 1975 to other countries. These changes in technology and environment created new realities for the Vietnamese people. One of those new realities is: How can Vietnamese people communicate with non-Vietnamese people, not just in formal asynchronous communication, but now everyday real-time communication? When you live, say, in the United States of America, or even if you lived in Vietnam communicating with English 
speakers on the internet, how do you deal with the fact that Vietnamese names Phúc (blessing) and Bích (emerald) are pronounced in English as vulgar terms "fuck" and "bitch"? Adopting Western names, while retaining Vietnamese surnames, is a cultural adaptation, for a very practical reason: when doing business with people who aren't fluent in Vietnamese, why waste time trying to educate them? There are probably other reasons that I haven't yet explored, such as cultural hegemony, but I'll keep this answer somewhat brief.

Also, I have seen throughout Vietnamese history that people could have multiple names. A good example is this person who was born Nguyễn Sinh Cung, and had aliases being Nguyễn Tất Thành and Nguyễn Ái Quốc. Today, we all know him most memorably as Hồ Chí Minh. And from personal experience, I have seen many Vietnamese Americans or recent Vietnamese immigrants coming to America adopt a Western name for everyday purposes, while maintaining usage of their Vietnamese name only among family and very close friends. Using aliases or having multiple names, seems to be an ancient Vietnamese "linguistic technology".

As for the second part of the original question, Can these half-foreign sounding names represent Vietnamese cultural identity? One of the properties of cultural identity is the concept of avowal and ascription. Avowal is how individuals expresses their identity being part of a group. Ascription is how others perceive the individual person (see Cultural Identity Theory).

I didn't understand this concept until recently, while I was editing for Wikipedia, particularly looking at List of Vietnamese Americans - Wikipedia. I noticed that someone listed rapper musician Tyga and described him as "Vietnamese and Jamaican rapper signed to Young Money and Cash Money Records". Tyga's maternal grandmother, Kim Nguyen, is Vietnamese. But I did not find evidence that he considered himself Vietnamese.

So, he might be Vietnamese by ascription (other people say he is Vietnamese), but perhaps not by avowal (he probably didn't call himself Vietnamese).

But here is where it gets even trickier. Ascription can be described using probabilities. Which means, perhaps $10 \%$ of other avowed (self-described) Vietnamese consider him Vietnamese, and $90 \%$ don't consider him Vietnamese. And you can actually plot this out into a Bayesian network (a network graph based on probabilities).

One of the most seminal work on Vietnamese cultural evolution (the study of changes in culture that draws a lot of parallels to Darwinian biological evolution) is Cultural evolution in Vietnam's early 20th century: A Bayesian networks analysis of Hanoi FrancoChinese house designs, which studied the architecture of multiple buildings of Hanoi's Old Quarter and plotted them on a graph based on the probabilities that any given building would contain Buddhist, Chinese, and/or French decorations. It is math heavy, 
but the key takeaway is that whether something is or is not Vietnamese might not be a binary yes/no answer, but rather a probability function. Although I don't know if there has yet been an application of Bayesian network analysis on cultural identity of people, it allowed me to look at everyone's answer who say "this person is Vietnamese" or "this person is not Vietnamese" as a ratio that could change over time. And it's based on whether the people say "I can relate to this other person" or "I cannot relate to this other person".

So if we're using names as a way to determine whether I can relate to a person or not, I offer you this personal experience as a Vietnamese American born in the United States: Whenever I see someone who has one of the common Vietnamese surnames (see Vietnamese name - Wikipedia), I get really excited, regardless of their given name. I have scanned the ending credits of many movies made by Hollywood looking for them. I will settle for even a "Susie Nguyen" and cry with joy inside thinking to myself:

"Vietnamese left our mark here". And even when I met non-Vietnamese women who married and adopted their husband's Vietnamese surname, I still got excited! It means Vietnamese are winning the hearts of non-Vietnamese in the world!

How will the other 100 million Vietnamese in the world think or relate? Probably a $5 \%$ chance of agreeing.

\section{References}

[1] Wikipedia. (n.d.) Cultural hegemony. Retrieved from: https://en.wikipedia.org/wiki/Cultural hegemony (accessed: Jan 5, 2021)

[2] Communication Theory. (n.d.) Cultural Identity Theory. Retrieved from: https://www.communicationtheory.org/cultural-identity-theory/ (accessed: Jan 5, 2021)

[3] Wikipedia. (n.d.) List of Vietnamese Americans. Retrieved from: https://en.wikipedia.org/wiki/List of Vietnamese Americans (accessed: Jan 5, 2021)

[4] Wikipedia. (n.d.) Bayesian network. Retrieved from: https://en.wikipedia.org/wiki/Bayesian network (accessed: Jan 5, 2021)

[5] Vuong QH, et al. (2019). Cultural evolution in Vietnam's early 20th century: A Bayesian networks analysis of Hanoi Franco-Chinese house designs. Social Sciences \& Humanities Open, 1(1), 100001.

[6] Wikipedia. (n.d.) Vietnamese name. Retrieved from: https://en.wikipedia.org/wiki/Vietnamese name\#Family name (accessed: Jan 5, 2021) 